\title{
Projeções para um Modelo de Adjudicação Administrativa de Conflitos nas Relações Laborais no Pós-Reforma Trabalhista e Pós- Extinção do MinistÉrio do Trabalho
}

\author{
Projections for a Non-judicial Model of Labor \\ Conflicts Resolution in the Post-brazilian \\ Labor Reform and Post-extinction of the \\ Ministry of LABOUR
}

\section{Proyecciones para un Modelo de Adjudicación Administrativa de Conflictos Laborales después DE la Reforma Legislativa Brasileña y la Extinción del Ministerio de Trabajo}

1 Aspectos introdutórios. 2 Breve restrospecto. 3 A mediação de conflitos trabalhistas nos anos 2000. 4 Uma conjuntura atual (ainda) em transformação. 5 Sobre o novo modelo de adjudicação administrativa de conflitos trabalhistas: algumas especulações. 6 Olhando para trás para enxergar os obstáculos à frente. 7 Considerações finais. Referências.

\footnotetext{
Mestre e doutor em ciências jurídicas e sociais (UFF). Economista (UERJ) e bacharel em direito (UNESA). Especialista em direito do trabalho e legislação social (UNESA). Auditor-Fiscal do Trabalho. Professor do Centro Universitário Geraldo di Biase. Professor colaborador da Escola Superior do Ministério Público da União, e da Escola Nacional da Inspeção do Trabalho. Membro da Associação Brasileira de Pesquisadores em Sociologia do Direito (ABraSD) e da Rede de Pesquisa Empírica em Direito (REED). Rio de Janeiro, RJ, BR. E-mail: <803monsores@gmail.com>. http://orcid.org/00000003-4056-3548
} 


\section{RESUMO}

Objetivo: Com a reforma trabalhista ocorrida no Brasil em 2017 e a extinção do Ministério do Trabalho em 2019, o modelo de adjudicação administrativa de conflitos trabalhistas, denominado "Mesa-redonda", sofreu um revés, tendo em vista a desarticulação estrutural da gestão do sistema brasileiro de relações de trabalho. $\mathrm{O}$ objetivo deste artigo é, justamente, examinar o atual contexto da administração estatal dos conflitos trabalhistas, especular sobre a possibilidade de reconstrução do modelo não jurisdicional de composição desses conflitos e, no limite, testar as condições para a reversão do processo de silenciamento das representações de classe, sobretudo dos sindicatos profissionais.

Metodologia: Este trabalho é uma contribuição teórica, de corte interdisciplinar, que, a despeito do acento jurídico, recebe aportes da sociologia e da economia política. Aplicase, predominantemente, o método dedutivo para a análise normativa e doutrinária, sem embargo de algumas sistematizações críticas de cenários e causalidades, nas quais se empregaram recursos da etnografia documental e da observação participante.

Resultados: Confirmaram-se as premissas iniciais. A primeira, que toma a extinção do Ministério do Trabalho brasileiro como evidência da (re)colonização da ordem social pela ordem econômica, contrariando a topologia constitucional vigente. A segunda, que a reforma trabalhista de 2017 foi determinante para a estratégia de silenciamento das nossas representações operárias. A terceira, que o modelo vigente de composição público-administrativa de conflitos trabalhistas é incompatível com a atual gestão das relações de trabalho no Brasil.

Contribuições: Além de trazer novos aportes para a compreensão do modelo brasileiro de mediação pública de conflitos trabalhistas (as Mesas-redondas) e da sua relação com o Sistema de Inspeção do Trabalho, este trabalho oferece lineamentos para uma reconfiguração paradigmática da gestão pública dos conflitos laborais, no âmbito do Sistema de Relações de Trabalho.

Palavras-chave: Mediação trabalhista. Mesas-Redondas. Relações de trabalho. Reforma trabalhista. Ministério do Trabalho.

\section{ABSTRACT}

Objective: After labor reform that took place in Brazil in 2017, and the extinction of the Ministry of Labour in 2019, the model of administrative adjudication of labor conflicts, called "Round Table", has suffered a setback, as a result of the structural disarticulation of the management of the Brazilian labor and union relations system. The purpose of 
Projeções para um modelo de adjudicação administrativa de conflitos nas relações laborais no pósreforma trabalhista e pós-extinção do Ministério do Trabalho

this article is, precisely, to examine the current context of the public administration of labor conflicts, to speculate about the possibility of reconstructing of this nonjurisdictional model for resolving labor conflicts and, at the limit, to test the conditions for the reversal of the process of institutional and discursive interdiction of class representations, especially of professional unions.

Methodology: This work is a theoretical and interdisciplinary contribution to the studies of labor relations in Brazil, that despite the legal accent, mobilizes some categories of sociology and political economy. The deductive method for normative and doctrinal analysis is predominantly applied. However, some critical systematizations of scenarios and causalities required resources and techniques from documentary ethnography and participant observation.

Results: The initial premises were confirmed. The first, which considers the extinction of the Brazilian Ministry of Labour as evidence of the (re)colonization of the social order by the economic order, in disagreement with the topological structure of the Brazilian Constitution. The second, that the 2017 labor reform was decisive for the strategy of silencing of workers' representations. The third, that the procedural model of publicadministrative composition of labor conflicts is incompatible with the current management of labor relations in Brazil.

Contributions: In addition to bringing new contributions to the understanding of the Brazilian model of public mediation of labor conflicts (the Round Tables), and its relationship with the Brazilian Labour Inspection, this work offers some references for a paradigmatic reconfiguration of the public management of labor conflicts, within the scope of the Brazilian Labor Relations System.

Keywords. Labor conflicts mediation. "Round Tables". Labor relations. Brazilian labor reform. Ministry of Labour.

\section{RESUMEN}

Objetivo: Con la reforma laboral que tuvo lugar en Brasil en 2017, y la extinción del Ministerio de Trabajo en 2019, el modelo de adjudicación administrativa de conflictos laborales, denominado "Mesa-redonda", ha sufrido un retroceso, ante la desarticulación estructural de la gestión del sistema brasileño de relaciones laborales. El objetivo de este artículo es, precisamente, examinar el contexto actual de la administración estatal de los conflictos laborales, especular sobre la posibilidad de reconstruir el modelo públicoadministrativo de composición de estos conflictos y, al final, probar las condiciones para la reversión del proceso de silenciamiento de las representaciones de clase, especialmente de los sindicatos profesionales. 
Metodología: Este trabajo es un aporte teórico, con un enfoque interdisciplinario. Aunque arraigado en la perspectiva legal, este artículo recibe contribuciones de la sociología y la economía política. Se aplica predominantemente el método deductivo para el análisis normativo y doctrinal, además de algunas sistematizaciones críticas de escenarios y causalidades, en las que se utilizaron recursos de la etnografía documental y la observación participante.

Resultados: Se confirmaron las premisas iniciales. El primero, que toma la extinción del Ministerio de Trabajo brasileño como evidencia de la (re)colonización del orden social por parte del orden económico, contrario a la actual topología constitucional brasileña. La segunda, que la reforma laboral de 2017 fue decisiva para la estrategia de silenciamiento de las representaciones de trabajadores. La tercera, que el modelo vigente de composición público-administrativa de los conflictos es incompatible con la gestión actual de las relaciones laborales en Brasil.

Contribuciones: Además de traer nuevos aportes para la comprensión del modelo brasileño de mediación pública de conflictos laborales (las Mesas-redondas), y su relación con el Sistema de Inspección del Trabajo, este artículo propone ofrecer pautas para una reconfiguración paradigmática de la gestión de los conflictos laborales, como política pública implementada bajo el sistema brasileño de relaciones laborales.

Palabras clave. Mediación laboral. Mesas-redondas. Relaciones laborales Reforma laboral brasileña. Ministerio de Trabajo.

\section{ASPECTOS INTRODUTÓRIOS}

Este artigo é uma contribuição teórica para a análise do modelo de mediação pública de conflitos trabalhistas, denominado Mesa-redonda. ${ }^{1}$ Trata-se, em verdade, de um novo capítulo de uma pesquisa veterana, iniciada há quase dez anos, que, desta feita, propõe-se a especular sobre possíveis reconfigurações daquele modelo alternativo à jurisdição que, até final de 2018, consistia numa das principais atribuições da Secretaria de Relações de Trabalho (SRT), do extinto Ministério do Trabalho (MTb).

Não é por outra razão que se adverte, desde logo, sobre o emprego referenciado de certos conceitos, fundamentos, categorias analíticas, relações e causalidades que

\footnotetext{
${ }^{1}$ A Mesa-redonda deixa o seu lugar de jargão oficioso, atribuído às formas procedimentais genéricas de composição público-administrativa dos conflitos trabalhistas, assumindo o status de processo administrativo em espécie, a partir da Portaria 3.122/88, que ainda se encontra em vigor.
}

99 • R. Opin. Jur., Fortaleza, ano 19, n. 31, p.96-126, maio/ago. 2021 
Projeções para um modelo de adjudicação administrativa de conflitos nas relações laborais no pósreforma trabalhista e pós-extinção do Ministério do Trabalho

foram, de fato, desenvolvidos e problematizados alhures e noutro momento, de modo que, nesta oportunidade, não serão reexaminados. ${ }^{2}$

No Brasil, o estado da arte sobre a mediação de conflitos trabalhistas, ainda que inserida no grande tema dos "meios alternativos de solução de controvérsias", a despeito do número expressivo de publicações, privilegia não mais que uma trinca de objetos de análise. De modo geral, o debate se concentra em torno das críticas ao instituto da conciliação, em sede processual-trabalhista (VIANA, 2007; NASSIF, 2009; GUNTHER; PIMPÃO, 2013; HILLESHEIM, 2015), das polêmicas sobre o impacto das comissões de conciliação prévia sobre o direito constitucional de acesso à justiça (MOHALlEM, 2000; OlIVA, 2002; CAMILO, 2008) ou das possibilidades de aplicação do rito arbitral aos conflitos que emergem dos contratos individuais de trabalho (MAGANO, 1986; PAMPLONA FILHO, 2005; ALMEIDA, 2008; MATTOS NETO, 2013; DALLEGRAVE NETO; GARCIA, 2018).

Esse contexto é, em parte, explicado pelo problema da polissemia que impregna o conceito de "mediação", o que acaba por restringir a abordagem acadêmica do tema quando aplicado aos conflitos laborais -, às considerações de caráter teóricometodológico, sem conexões aparentes com modelos institucionalizados, o que dificulta a abordagem empírica e interdisciplinar. ${ }^{4}$

Outra questão que parece transcender o caso brasileiro, considerando a mediação em sua qualidade de "negociação assistida", diz respeito ao status do patrimônio econômico-jurídico de natureza trabalhista. Não se está a afirmar, tão só, o dogma da natureza alimentar do crédito salarial ou da condição hipossuficiente do trabalhador, traço constituinte de sua ontologia (CESARINO JÚNIOR, 1940). Para além, trata-se de um estranhamento, talvez um tabu, uma vez que os princípios que informam a mediação ${ }^{5}$, ademais de sua espacialidade eminentemente privada, parecem negar o direito de resistência operária e, por tabela, a própria luta de classes.

No Brasil, contudo, o projeto de cidadania salarial regulada constituiu e conservou o Estado como o grande mediador do conflito trabalhista. Aquele

\footnotetext{
${ }^{2}$ São exemplos: a distinção entre conflitos de interesses e direitos; a polissemia acerca do conceito de "mediação"; o paradigma de legalidade das Mesas-redondas determinado pelo Sistema de Inspeção do Trabalho; a reorganização da fiscalização trabalhista a partir da vocação arrecadatória; o esvaziamento do Sistema de Relações de Trabalho, no que se refere à atuação dos Fiscais do Trabalho (atuais Auditores-Fiscais do Trabalho [AFTs]), "integração" intersistêmica e interinstitucional, dentre outros.

${ }^{3}$ Atualmente, o sistema de justiça tem preferido adotar a terminologia "meios adequados de solução de conflitos" (MASCs) ou "resolução adequada de disputas" (RADs), em lugar da tradicional terminologia "meios alternativos de solução de disputas" (do inglês ADR: Alternative Dispute Resolutions). Segundo o Conselho Nacional de Justiça (CNJ), a mudança terminológica denotaria a "escolha consciente de um processo ou método de resolução de conflitos, entre vários possíveis, considerando o contexto fático da disputa" (BRASIL, 2015, online).

${ }^{4}$ Exemplos de estudos com tais características podem ser vistos em Jazzar (2008) e Bastazine (2012).

${ }^{5}$ Muitos deles positivados pela nossa "Lei Geral da Mediação" (13.140/2015).
} 
estranhamento, então, é atenuado pela reinterpretação do conflito, segundo o algoritmo binário do direito - lícito/ilícito - de modo que o Estado, além de mediador, é também o garante da segurança jurídico-institucional.

Decerto que o Estado, ao fustigar a liberdade negocial, problematiza o próprio conceito de mediação, de modo que a pergunta a seguir faz sentido: existe, de fato, mediação trabalhista no Brasil?

A contradição aqui expressa é "contornada", no âmbito judicial, não só pela transfiguração do conflito em lide, mas também (e principalmente) do direito em crédito trabalhista, constituído ex ante e ex post ao término do vínculo empregatício, à propositura da ação e/ou liquidação da sentença. ${ }^{6}$

O que pouco se sabe é que tal contradição também se reproduz fora do sistema de justiça, no quase desconhecido cenário da adjudicação público-administrativa dos conflitos laborais, no âmbito do extinto MTb. Sem embargo, o dilema enfrentado não diz respeito, em princípio, à questão da disponibilidade dos direitos trabalhistas (embora haja espaço para considerações acerca da sua controvérsia ou incerteza), e sim à (in)derrogabilidade da punição administrativa.

Esse dilema reforça a tese de que o modelo de mediação público-administrativa de conflitos, desenvolvido no âmbito do Sistema de Relações de Trabalho do $\mathrm{MTb}^{7}$ é, de fato, um aspecto da própria trajetória evolutiva do Sistema de Inspeção do Trabalho brasileira. Contar a história de um é contar a história do outro.

Desse modo, as projeções que aqui se fazem são antecedidas de uma breve retrospectiva dos modelos de mediação trabalhista, historicamente contextualizada em sua interface com a Inspeção do Trabalho, seguida de um exame da conjuntura atual, considerando o enfoque interdisciplinar da escola regulacionista e sua influência sobre a teoria do Estado (JESSOP, 2008).

Nesse sentido, assume-se, como premissa, que os ciclos políticos e econômicos, na medida em que se sucedem, estabelecem novos compromissos institucionalizados que

\footnotetext{
${ }^{6}$ Para uma crítica a esta posição fortemente defendida pelo sistema de justiça, ver Nassif (2009).

${ }^{7}$ Neste texto, a expressão multicitada: "Sistema de Relações de Trabalho", normalmente assinalada com maiúsculas, tem cunho institucional, cujo sentido se traduz em termos administrativistas, dizendo respeito às estruturas ou complexos político-administrativos, dotados de atribuições consultivas, executivas e normativas. O Sistema de Relações de Trabalho atua como um elo entre o Estado e as representações categoriais de trabalhadores e empregadores. Ele se constitui como forma institucional e agente operador do modelo sindical brasileiro, no que tange à certificação das entidades sindicais e ao armazenamento dos acordos e convenções coletivas. Mas sua atuação, em verdade, não se limita à manutenção do Cadastro Nacional de Entidades Sindicais (CNES) e ao depósito, registro e arquivamento dos instrumentos normativos. Ele também administra o modelo de mediação dos conflitos de direitos e interesses laborais coletivos, entre sindicatos de categorias econômicas e profissionais, e individuais, entre trabalhadores e empresas. Em sentido semelhante, aplica-se a expressão "Sistema de Inspeção do Trabalho", no que se refere à fiscalização do cumprimento das leis trabalhistas, inclusive no que tange às condições de higiene e segurança do ambiente laboral.
}

101 R. Opin. Jur., Fortaleza, ano 19, n. 31, p.96-126, maio/ago. 2021 
Projeções para um modelo de adjudicação administrativa de conflitos nas relações laborais no pósreforma trabalhista e pós-extinção do Ministério do Trabalho

invocam novos modos de regulação do regime de acumulação capitalista, os quais irão demandar um tipo específico de intervenção estatal, neste particular, por meio de formas adjudicatórias de conflitos centrados nas relações de trabalho.

As evidências que surgem da análise dos textos normativos e da etnografia documental, que orientam metodologicamente esta pesquisa, desde o seu início, apontam para uma ressignificação do modelo de composição de conflitos trabalhistas que, por outros meios e razões distintas, revisita o pressuposto estadonovista da natureza anômica do conflito, negando-lhe a qualidade de fenômeno essencial e estruturante da relação capital x trabalho.

\section{BREVE RESTROSPECTO}

Sem retroagir aos modelos de ignição que operavam desde a vigência da Constituição Federal de 1891, até a sua reconfiguração e apropriação pelo sistema de justiça, afora o processo administrativo de anotação da Carteira de Trabalho e Previdência Social - CTPS (arts. 36 a 39 da CLT), a mediação trabalhista volta a ganhar os holofotes, no âmbito do Ministério do Trabalho, a partir das mudanças advindas com o Decreto-Lei no 229/67.

O contexto de ocasião indicava que o papel da mediação administrativa de conflitos coletivos, patrocinada pela reforma trabalhista decretada pelo regime militar, pouco se distinguia daquele definido pela agenda estadonovista. $O$ nível de intervenção estatal, desde logo, sugerido pelo impulso convocatório imposto aos sindicatos e às empresas, fincou raízes, mesmo depois da redemocratização.

De certo modo, é compreensível que tenha sido assim, uma vez que, a despeito do caráter interventivo do modelo, conflitante com o Texto Constitucional de 1988, o D.L. 229/67 dialogava, em termos principiológicos, com a inescusabilidade negocial imposta aos entes coletivos - empresas e sindicatos - pela própria Constituição Federal de 1988 (CRFB/88). ${ }^{8}$

Em sendo assim, a primeira conclusão a que se chega é que a mediação de conflitos coletivos, patrocinada pelo Estado Brasileiro, carrega consigo a herança interventiva que definia a centralidade estatal, no âmbito da concertação corporativista.

Isso ajuda a explicar o histórico protagonismo dos Inspetores do Trabalho, também no âmbito do Sistema de Relações de Trabalho, sem embargo da estranheza

\footnotetext{
8 Tal princípio, aliás, emerge da inédita tutela constitucional da negociação coletiva; uma tutela específica e bifacetada, pois, ao tempo de reproduzir, em contexto democrático, a legitimidade representativa dos corpos intermédios, também é reconhecida como um direito inalienável dos grupos profissionais e econômicos. Diz-se, então, que a ordem constitucional vigente não trata a negociação coletiva "de costas". Ao invés, joga sobre ela um "facho de luz", afirmou certa feita o Prof. Lima Teixeira (SÜSSEKIND et al., 2005, p. 1193).
} 
manifestada em 2006 por alguns membros da ACAS $^{9}$ britânica, durante um intercâmbio negociado entre o MTb e a embaixada do Reino Unido. Para eles, não era compreensível que o agente público entronizado pelo poder-dever de punir era, ao mesmo tempo, um mediador dos conflitos; os mesmos que surgem, com frequência, em contextos de descumprimento da lei.

De fato, no âmbito dos chamados "conflitos de direito", coletivos ou individuais, tal contradição emerge ainda mais nítida, porquanto o mediador, agente da inspeção do trabalho, age orientado por um télos de caráter narrativo que o identifica previamente como um "protetor do trabalhador" (ASSUMPÇÃO, 2018). Assim sendo, não se supõe, definitivamente, que o papel autêntico de "mediador" se sustente, ainda que não haja conexão necessária (procedimental) entre a Mesa-redonda e a fiscalização trabalhista.

Nesse sentido, a "autoridade" do mediador-fiscal se converte em "poder mantido em reserva” (GEORGE, 1891, p. 33), espécie de coerção simbólica que paira latente sobre o ambiente negocial. Uma autoridade, todavia, que não se baseia, imediatamente, na expertise jurídica, mas no poder que advém de sua prerrogativa legal de reconhecer e construir tipos puníveis, de acordo com a lei, a partir de sua própria percepção da realidade concreta.

É por isso que, considerando as demandas e o contexto atual, qualquer exame do nosso modelo de mediação de conflitos estaria incompleto, sem compreendê-lo em sua interação com a Inspeção do Trabalho.

Parágrafos atrás nos referimos à "mediação" assim, entre aspas, porque, de fato, a adjudicação administrativa dos conflitos trabalhistas não se inscreve, tão só, como negociação assistida. Em primeiro lugar, porque não se abdica da ação do Estado regulador, visto que o modelo nomeado Mesa-redonda é um processo administrativo em espécie, regulamentado prima facie pela Portaria no 3.122/88 (ASSUMPÇÃO, 2012). Nessa norma, prevê-se a ocorrência da mediação e da conciliação como institutos metodologicamente distintos, o que, de fato, são. Por outro lado, os regimentos que se sucederam após a edição da Portaria no 3.122/88, tanto da estrutura central do então MTb quanto das Superintendências e Gerências Regionais mencionam expressamente a arbitragem como atribuição do sistema de relações de trabalho.

Nesse sentido, o termo "mediação", no nosso caso, é despojado de qualquer rigor técnico, pois denomina um modelo de adjudicação de conflitos que mobiliza todo o espectro de atuação considerada alternativa à jurisdição, isto é, a mediação, a conciliação e a arbitragem, bem como suas formas transitórias, híbridas e mitigadas.

Historicamente, desde a criação do Departamento Nacional do Trabalho (DNT), a fiscalização trabalhista estava inserida conceitual e estruturalmente no âmbito do Sistema de Relações de Trabalho. O que se poderia chamar de emancipação sistêmica só

\footnotetext{
${ }^{9}$ Advisory, Conciliation and Arbitration Service (https://www.acas.org.uk/).
}

103 - R. Opin. Jur., Fortaleza, ano 19, n. 31, p.96-126, maio/ago. 2021 
Projeções para um modelo de adjudicação administrativa de conflitos nas relações laborais no pósreforma trabalhista e pós-extinção do Ministério do Trabalho

ocorreu em meados da década de noventa, embora seja correto afirmar que tanto em razão da memória estrutural do Ministério do Trabalho quanto pela solidariedade funcional entre Fiscais do Trabalho atuantes em ambos os sistemas, Inspeção e Relações de Trabalho se mantiveram relativamente conectados até perto de 2003 (ASSUMPÇÃO, 2014, 2015), dentre outras razões porque:

a) em 1992, com a edição da IN no 02, de 12 de março, o procedimento de homologação da rescisão contratual incorporou o conceito de "assistência e prevenção da litigiosidade”, autorizando o Fiscal do Trabalho a atuar como conciliador ou árbitro, em situações de conflitos oriundos de divergências na conta resilitória, expressa no Termo de Rescisão de Contrato de Trabalho (TRCT);

b) anunciado como um dos fundamentos da norma citada anteriormente, advêm os primeiros sinais de um processo de comprometimento do acesso à justiça (trabalhista), pelo aumento da judicialização, sobretudo coletiva (planos econômicos dos anos 80; mudança de estatuto jurídico dos empregados públicos; aumento extraordinário do número de sindicatos nos primeiros anos pós-CRFB/88; endurecimento do TST, com relação ao exercício do direito de greve), o que levou à edição da Instrução Normativa TST no 04, de 8 de junho de 1993;

c) o desenho institucional da Inspeção do Trabalho brasileira, firmado pela Portaria Interministerial $n^{\circ}$ 06/1994, caracterizava-se por uma grande permeabilidade social, compreendendo não só as formas organizadas de representação profissional e econômica, mas também empregados e empregadores em suas demandas individuais ou coletivizadas;

d) a introdução do componente patrimonial-restitutivo à ação fiscal, como forma de dar sentido prático ao télos protetivo atribuído à Inspeção do Trabalho, que fora legitimado pela CRFB/88, para além do argumento pro domo (ASSUMPÇÃO, 2018, p. 194);

e) a valorização, para efeito quantitativo, dos resultados fiscais que traduzissem solução de problemas concretos, sempre nas circunstâncias em que tais admitissem uma tradução patrimonial ou uma ressignificação em termos de estatuto jurídico, como se veem nos casos de pagamento de rubricas salariais, recolhimento de FGTS, quitação de verbas resilitórias, reconhecimento de vínculos empregatícios etc. Nesse sentido, o Auto de Infração se desloca do seu lugar tradicional, de manifestação necessária e suficiente da autoridade do Estado-Policial, na medida em que incorpora o registro simbólico da ultima ratio, diante do insucesso ou inviabilidade do esforço fiscal saneador; 
f) a extinção gradativa da política oficial de reposição salarial, o que, ao tempo de valorizar a negociação coletiva, impulsionando sua regulamentação nesse particular, também gerou enorme demanda por espaços de concertação, não só em razão dos impasses durante as tratativas, mas também devido à reivindicação de acesso ao "direito de negociar";

g) a campanha doutrinal intitulada "O Novo Perfil da Fiscalização do Trabalho", introduzida no final dos anos 90, cuja orientação neoliberal propunha a reconfiguração da Inspeção do Trabalho para além de sua atribuição de controle e vigilância;

h) a inserção do componente negocial na Inspeção do Trabalho, com o advento da Mesa de Entendimento, e de um juízo de conveniência, de índole moral, que resgata o conceito jurídico do animus infringendi, introduzido na política inspecional por Marcondes Filho, em 1942, e reproduzido em todos os manuais internos, desde 1960. Vale dizer que esse conceito ingressa num processo de esgotamento a partir de 2010, como consequência dos desdobramentos da Portaria $n^{\circ} 546 .^{10}$

Com exceção das mediações coletivas baseadas em interesses, tem-se que a mediação de conflitos de direitos se desenvolveu no pós-CRFB/88 como uma extensão ou alternativa funcional da Inspeção do Trabalho. Num primeiro momento, como forma de caracterizar o perfil restitutivo e produzir uma conexão com a sociedade do trabalho para além do Estado-Policial. Num segundo momento, como estratégia de arrefecimento da intervenção estatal no domínio da produção.

\section{A MEDIAÇÃO DE CONFLITOS TRABALHISTAS NOS ANOS 2000}

O advento das Mesas de Entendimento ${ }^{11}$ no final da década de 90, a despeito de se tratar de um procedimento inspecional, acabou por impulsionar o modelo de mediação conduzido pelo Sistema de Relações de Trabalho. Esse efeito, contudo, foi transitório, e não avançou por mais de três anos, após a virada do século.

De fato, o texto anterior do art. 628 da CLT não parecia obstar o desenho saneador e restitutivo adotado pela Inspeção do Trabalho no pós-CRFB/88, a partir de

\footnotetext{
${ }^{10}$ A Portaria n ${ }^{\circ} 546 / 2010$ (BRASIL, 2010), que foi revogada e substituída pela Portaria n ${ }^{\circ} 643 / 2016$ (BRASIL, 2016), produziu uma importante reconfiguração da política inspecional do trabalho, inaugurando o que ficou conhecido como "fiscalização por projetos".

${ }^{11}$ As Mesas de Entendimento foram regulamentadas a partir da inclusão na CLT do art. 627-A e atualmente atendem pela expressão genérica "procedimento especial de fiscalização". Portanto, sendo espécie de procedimento inspecional, a Mesa de Entendimento não se confunde com a Mesa-redonda, que é o nomem juris do processo administrativo e, também, da reunião de mediação de conflitos. Tratase, portanto, de atribuições próprias, respectivamente, do Sistema de Inspeção do Trabalho e do Sistema de Relações de Trabalho.
}

105 R. Opin. Jur., Fortaleza, ano 19, n. 31, p.96-126, maio/ago. 2021 
Projeções para um modelo de adjudicação administrativa de conflitos nas relações laborais no pósreforma trabalhista e pós-extinção do Ministério do Trabalho

1994. Contudo, a referência expressa ao procedimento especial, a partir de 2001, retirou o fôlego do elemento de cognição fiscal, reproduzido no verbo regente "concluir" (pela infração). Reinterpretado como um ato de mera subsunção, "concluir" se torna "constatar", cujo sentido sempre foi residual, reproduzido, unicamente, no âmbito da fiscalização de segurança e saúde no trabalho, no contexto da maior expressão interventiva da Inspeção do Trabalho brasileira: o embargo e a interdição.

Além disso, com a introdução do procedimento especial no âmbito do Sistema de Inspeção do Trabalho, o elemento negocial mobilizado pelo AFT, que, até então, formalmente, se dava no âmbito de sua atuação em Mesa-redonda, é reapropriado pela práxis inspecional, marginalizando e deslegitimando a atuação subsidiária da mediação, no âmbito dos conflitos baseados em direitos.

A partir de 2004, a Inspeção do Trabalho sinaliza um movimento importante, de "purificação funcional", sob a égide do que se convencionou chamar, conforme a própria narrativa da Secretaria de Inspeção do Trabalho (SIT), de "atividade inerente à carreira”. Em verdade, trata-se de um duplo movimento. Para fora, no âmbito das tensões interinstitucionais, verifica-se a adesão ao grupo fisco. ${ }^{12}$ Para dentro, no âmbito da própria arquitetura do MTb, tem-se a "endodiferenciação", em nome da fiscalização propriamente dita.

A ruptura estrutural com o Sistema de Relações de Trabalho que, em tese, já havia ocorrido na década anterior, tornou-se uma diretiva orgânica, coerente com uma ideologia inspecional que invocava o expurgo de todas as atividades que não fossem autênticas expressões da auditoria fiscal.

Sem problematizar essa questão, o que importa reter, nesse momento, é que o processo cada vez mais hermético de encerramento dos Auditores-Fiscais do Trabalho, no âmbito do perímetro do sistema inspecional, não foi resultado tão só das estratégias de resiliência da Inspeção do Trabalho (ASSUMPÇÃO, 2019b), mas, igualmente, de uma diretriz governamental orientada, neste particular, pelo compromisso com a democratização das relações de trabalho.

Essas diretrizes, contudo, não são propriamente antagônicas, nem necessariamente convergentes. São, antes de tudo, tensionadas, portanto, concorrentes, de modo que as evidências desse processo de exclusão dos AFTs do Sistema de Relações de Trabalho são, por vezes, contraditórias.

Senão vejamos:

a) investimento maciço na qualificação de mediadores, entre 2003 e 2006, envolvendo parcerias com o DIEESE e com órgãos internacionais (e.g. ACAS), extensível a AFTs e Agentes Administrativos;

\footnotetext{
${ }^{12}$ Expressão que seguiu ao tradicional "Grupo TAF” (Tributação, Arrecadação e Fiscalização), que agregava os agentes da fiscalização de tributos federais.
} 
b) discurso de "purificação" da Inspeção do Trabalho, impulsionado, de início, pelo imperativo da produtividade fiscal (metas institucionais) como condição remuneratória. Posteriormente, como resposta ao enxugamento do quadro de AFTs. O ápice desse processo foi a emissão de Nota Técnica pela SIT (016/2011) em que se nega competência do AFT para conduzir os processos de registro de CTPS e realizar mediações;

c) regimento interno das Superintendências, reconfigurado em 2009, criou "áreas de exclusão" dos AFTs, nomeadamente no Sistema de Relações de Trabalho (SEMEDs e SERTs);

d) ao lado do discurso de purificação, observa-se uma "purificação do discurso" da Inspeção do Trabalho, no âmbito do qual se invoca, inclusive, a própria Convenção no 81 da OIT. O resultado mais imediato pode ser descrito como uma postura inspecional asséptica da narrativa sindical, o que se acentuou a partir de 2010, com a edição da Portaria no 546;

e) o Auto de Infração se torna o desfecho necessário e suficiente da ação subsuntiva da Inspeção do Trabalho, que, além de incorporar, imediatamente, a expressão de autoridade, se converte numa versão reducionista do tecnicismo que sempre caracterizou o ideal tipo de fiscalização trabalhista, desde a Recomendação no 20 de 1923 da OIT;

f) o próprio Sistema de Relações de Trabalho, no que se refere à mediação de conflitos baseados em interesses, buscou alternativas para a redução da participação dos AFTs. Uma das evidências dessa reorientação foram os programas de qualificação de mediadores, entre 2010 e 2012, prioritariamente dirigidos aos Agentes Administrativos. Esse reposicionamento da SRT tanto pode ser uma resposta ao encerramento dos AFTs no Sistema de Inspeção do Trabalho quanto uma diretiva coordenada com a agenda da democratização das relações de trabalho, possivelmente conflitante com a expressão de autoridade manifestada pelo AFT, mesmo na condição de mediador;

g) sofisticação crescente dos sistemas telemáticos aplicados (também) à Inspeção do Trabalho, que, a propósito de aperfeiçoar e agilizar as rotinas da fiscalização trabalhista, concorrendo para o aumento da produtividade e padronização do sistema inspecional, converteu-se, igualmente, numa poderosa ferramenta de controle cibernético sobre as etapas do processo de trabalho do AFT. Nesse sentido, o "sistema" se converte em forma normativa sui generis, determinando a organização, o ritmo e a administração do tempo, além dos critérios de validade dos resultados do trabalho inspecional. Essa hermeticidade sistêmica aumentou ainda mais o abismo entre a Inspeção e o 
Projeções para um modelo de adjudicação administrativa de conflitos nas relações laborais no pósreforma trabalhista e pós-extinção do Ministério do Trabalho

Sistema de Relações de Trabalho, pois, ao contrário deste, a fiscalização "sistematizada" prescinde das nuances narrativas dos trabalhadores, dos empregadores e do próprio AFT, como etapas obrigatórias do processo de construção das múltiplas realidades do "mundo do trabalho". Essa "dessubjetivação" das relações de trabalho, como um contraponto do esforço produtivista da Inspeção do Trabalho do século XXI, se encerra numa recursividade operativa hostil às permeabilidades com o meio social, verdadeira razão de ser do Sistema de Relações de Trabalho;

h) por outro lado, o próprio Sistema de Relações de Trabalho se rende à rotinização procedimental controlada. O Sistema Mediador ${ }^{13}$, merecedor de todos os elogios como ferramenta de mapeamento, estatística e publicização dos instrumentos normativos, é, ao revés, extremamente problemático como gestor do modelo de mediações em Mesa-redonda. Com o auxílio luxuoso do igualmente criticável Homolognet ${ }^{14}$, a mediação individual ou plúrima de conflitos de direitos praticamente desaparece, sobrevivendo em algumas unidades quase como um "desvio procedimental".

\section{UMA CONJUNTURA ATUAL (AINDA) EM TRANSFORMAÇÃO}

$\mathrm{Na}$ maior parte da longa trajetória da adjudicação judicial e administrativa de conflitos trabalhistas pelo Estado Brasileiro, a mediação, a conciliação e a arbitragem (para os que defendem tal papel atribuído aos dissídios coletivos) operavam enquanto mecanismos de "pacificação social" (internal social peace). ${ }^{15}$

Todavia, a oferta de espaços estatais de negociação e composição, como política pública, contrastava, paradoxalmente, com uma doutrina centrada na negação do próprio conflito, que subjaz praticamente inalterada nas quase seis décadas que se seguiram à ascensão do Estado Novo. O que alternou, ao longo do tempo, foi o interesse público politicamente anunciado e emulado na linguagem constitucional. Num primeiro momento, a proscrição do direito coletivo de resistência social, num segundo, a harmonia de classes e, num terceiro, a despolitização do movimento operário.

\footnotetext{
${ }^{13}$ Subsistema vinculado ao Sistema Integrado de Relaç̃es de Trabalho (SIRT), que se presta ao depósito, registro e arquivamento dos instrumentos normativos (acordos e convenções coletivas) e gerenciamento dos processos de Mesa-redonda.

${ }^{14}$ Tal como o Mediador, o Homolognet é um subsistema do SIRT, por meio do qual era realizada a assistência homologatória das rescisões trabalhistas dos contratos com duração superior a um ano.

${ }^{15}$ Referência aos "Internal social peace treaties", designação de Philippe C. Schmitter ao examinar as estratégias de concertação social adotadas por alguns países europeus (ex. Suécia, Holanda, Dinamarca e Suíça) durante os anos 40, em conformidade com o paradigma corporativista. Conferir em "Still the Century of Corporatism?" (SCHIMITTER, 1974).
} 
Os ares democráticos advindos com a CRFB/88 pôs por terra esses três grandes atavismos, ao tempo que:

a) reconhece o conflito capital $\mathrm{x}$ trabalho como elemento estruturante do Estado Capitalista Constitucional Brasileiro (ECCB);

b) garante a autotutela operária e eleva a negociação coletiva à condição de direito fundamental coletivo;

c) cria uma topologia constitucional para a ordem social e, com ela, a promessa de uma cidadania salarial autorregulada;

d) proclama a democracia como o registro político das relações de trabalho, empoderando sobremaneira as representações sindicais.

A despeito das críticas que se fazem ao processo de precarização do trabalho, como um desdobramento da agenda neoliberal introduzida no Brasil nos anos 90, não seria honesto negar que praticamente todas as formas precárias de contratualização do trabalho assalariado dependiam, para sua implementação, da deliberação categorial em sede de negociação coletiva (SILVA, 2011).

Admite-se que tal constatação seja, talvez, de pouca valia, pois também é verdade que diversos processos concorreram para a fragilização da representação sindical no Brasil, tais como: explosão de sindicatos na virada das décadas de 80 e 90; papel de "contenção" da resistência operária atribuído ao TST (SILVA, 2008); formas inautênticas de trabalho associado e terceirização; influência da automação no encolhimento do emprego, sobretudo em atividades outrora trabalho-intensivas etc. Como consequência, é provável que algumas pautas precarizantes tenham sido, de fato, endossadas sem muito esforço por intermédio da negociação coletiva.

Todavia, não se pode atribuir aos governos neoliberais da década de 90, tampouco aos governos frequentemente denominados, com razão ou sem ela, "pósneoliberais"16, a partir de 2003, a ocorrência de um compromisso estatal (institucionalizado) com o silenciamento das representações classistas.

É claro que as formas representativas de interesses do capital se mantiveram fortes e influentes. Mas muita reserva de poder foi formalmente garantida aos sindicatos profissionais, tendo em vista os diversos episódios legais de condicionamento à negociação coletiva, seja no âmbito da adoção dos novos estatutos jurídicos do trabalho assalariado, das formas de organização do tempo do trabalho, das concessões em prol da ordem econômica e mesmo da administração dos conflitos coletivos.

\footnotetext{
${ }^{16}$ Para uma proposta de conceito, ver Sader e Gentilli (2009) e Sader (2013). Para uma crítica da aplicação do conceito ao contexto brasileiro, especificamente quanto ao governo Lula, ver Boito Júnior (2002, 2003).
}

109 R. Opin. Jur., Fortaleza, ano 19, n. 31, p.96-126, maio/ago. 2021 
Projeções para um modelo de adjudicação administrativa de conflitos nas relações laborais no pósreforma trabalhista e pós-extinção do Ministério do Trabalho

Até o autofinanciamento do sistema de representação sindical, inicialmente fustigado pelo Precedente do TST no 119 e, adiante, pela Súmula do STF no $666^{17}$, foi parcialmente remediado pelo oportuno "direito de oposição" ${ }^{18}$, inclusive com o apoio, na origem, do próprio MPT e a abstenção do MTb, a despeito do "erro estratégico" advindo com a Portaria MTE no 160/2004.

Mas num processo que dá seus primeiros sinais ainda em 2014, com a reversão de tendência quanto à admissibilidade do autofinanciamento sindical, pela via da deliberação coletiva, vislumbra-se no ano de 2017, com a Lei 13.467 (Reforma Trabalhista) (BRASIL, 2017), a ocorrência de um episódio disruptivo na trajetória do sistema brasileiro de representação sindical, o que se pode atestar pelas seguintes evidências:

a) banalização das formas excepcionais de organização do tempo do trabalho e da administração dos descansos, seja pela cassação da jurisprudência específica, seja pela glorificação do poder empregatício, expresso dos acordos individuais;

b) criação de zonas de exclusão sindical, nomeadamente no que se refere à representação laboral no âmbito das empresas;

c) ruptura com o modelo de financiamento compulsório do sistema de representação sindical, em nome da liberdade associativa;

d) proibição do autofinanciamento sindical, por meio da autonormatividade (acordos e convenções coletivas);

e) reconhecimento do caráter de potestade patronal da decisão pela dispensa coletiva de trabalhadores, as chamadas "demissões em massa";

f) tentativa de deslegitimar a deliberação assemblear, como instrumento de adesão coletiva ao desconto da contribuição sindical, e de impedir a dedução em folha de pagamento da mensalidade social (MP no 808/2017);

g) possibilidade de convenção de arbitragem por meio de cláusula compromissória em contrato individual de trabalho;

h) criação de formas ainda mais precárias de trabalho, desta feita sem qualquer condicionamento em negociação coletiva.

O cenário se agudiza a partir de 2019, com o desaparecimento do Ministério do Trabalho, que, no contexto da CRFB/88 espelhava, administrativamente, a emancipação da ordem social. Com o encerramento das políticas de seguridade, trabalho e renda no âmbito do superministério da economia, subjuga-se a ordem social à ordem econômica, estratégia que ainda se encontra em processo de aprofundamento.

\footnotetext{
${ }^{17}$ Convertida, posteriormente, na Súmula Vinculante ${ }^{\circ} 40$.

${ }^{18}$ Cláusula normativa que se tornou condição de admissibilidade para o autofinanciamento sindical, por meio de contribuições assistenciais fixadas em acordos ou convenções coletivas.
} 
Por sua vez, a administração do "problema sindical" volta a ser um caso de polícia, incorporada que foi, inicialmente, ao rol de atribuições do Ministério da Justiça.

Entre outras, trata-se de evidência de uma política de contenção da autonomia sindical e de degeneração do ente coletivo profissional, como um caso particular de algo maior, recorrentemente descrito como a radicalização do paradigma liberal clássico, e da visão atomizada de organização social, cuja ordem e contexto invocam, obviamente, o silenciamento das formas de representação coletiva (ASSUMPÇÃO, 2019a).

Supondo consistentes os argumentos até aqui esboçados, pergunta-se, então: como se estruturaria, nesse momento, um modelo de adjudicação de conflitos trabalhistas? Sob que propósito se justificaria, dessa vez, a intervenção estatal no âmbito das relações de trabalho?

\section{SOBRE O NOVO MODELO DE ADJUDICAÇÃO ADMINISTRATIVA DE CONFLITOS TRABALHISTAS: ALGUMAS ESPECULAÇÕES}

Considerando a atual conjuntura, em termos de formulação de uma política pública de relações de trabalho no Brasil, custa-nos crer num modelo estatal de composição de conflitos coletivos baseados em interesses, mesmo de direitos, que não se proponha a retomar alguns dos paradigmas de outrora, seja a contenção das formas de autotutela das categorias profissionais, seja a redução do intervencionismo do EstadoPolicial, representado pela Inspeção do Trabalho.

No âmbito dos conflitos individuais, é possível que um modelo adjudicatório tome como referência uma expressão atomizada da sociedade do trabalho. Um modelo que, em princípio, seja hermético às representações sindicais. Nesse sentido, o paradigma consumerista para a percepção de satisfação, representado por uma espécie adaptada de "Reclame Aqui", pode, de fato, ter um alcance notável.

Por outro lado, considerando os limites do protocolo automatizado aplicável a esses modelos, é problemático afirmar a existência de um efetivo controle estatal do cumprimento das normas trabalhistas. Em se tratando de um modelo público, da mesma forma que as pesquisas de satisfação do consumidor, será o mercado, e não o Estado quem exercerá o papel de garante do sistema de proteção social.

A força desses modelos está, justamente, no constrangimento público que decorre da exposição virtual dos marcadores de (in)satisfação com a prestação de serviços e com a qualidade dos produtos, além do comprometimento com a solução de problemas. Às vezes, esses marcadores se reproduzem nos balanços sociais, modificando negativamente a situação das empresas em seus respectivos sistemas peritos (GIDDENS,1991). Às vezes, irradiam-se pelas redes sociais, que, nesse caso, também 
Projeções para um modelo de adjudicação administrativa de conflitos nas relações laborais no pósreforma trabalhista e pós-extinção do Ministério do Trabalho

atuam como sistemas peritos, gerando uma acrítica indisposição coletiva para o consumo de determinados bens e serviços.

Mas esses protocolos não dispõem, via de regra, de uma rotina relacionalpresencial (portanto, não algorítmica) de solução de controvérsias, pois a abordagem atomizada dos conflitos, hermética às formas de representação coletiva, demanda uma estrutura igualmente capilarizada, circunstância que, em se tratando de um modelo administrativo de solução de conflitos trabalhistas, no âmbito de um "autêntico" Sistema de Relações de Trabalho, imporia ao Estado uma enorme pressão orçamentária.

É bem verdade que os modelos de defesa de direitos, baseados no paradigma consumerista, apresentam-se como formas customizadas e personalizadas, todavia só na aparência, pois a lógica probabilística de seus algoritmos (perguntas ou dúvidas mais frequentes, procedimentos preliminares etc.) opera a partir de um aprendizado cumulativo, ou seja, por meio de um incessante processo de classificação de cases, que facilita a solução de problemas com um razoável compromisso com a satisfatividade, a um custo igualmente razoável.

É possível que o paradigma consumerista, como vetor dominante dos modelos de defesa de direitos possa, de fato, gerar eventos de crítica social, pelos meios já mencionados anteriormente. Contudo, a assistência pretensamente individuada, o descompromisso identitário e a hermeticidade em relação às formas de representação coletiva de interesses tornam aqueles eventos, se muito, meros episódios de coalizão, sem pretensão organizativa, pois, na base do modelo, supõe-se que o próprio conflito é episódico e não estruturante daquela relação sociojurídica que o modelo pretende estabilizar.

A questão que nos parece central, quando se fala de uma estrutura de adjudicação de conflitos trabalhistas, no âmbito do Ministério da Economia, diz respeito ao tipo de interação intersistêmica: Relações de trabalho e Inspeção do Trabalho.

Partindo de um modelo aberto, em termos de regulamentação, as experiências de mediação se desenvolveram pelo Brasil do pós-CRFB/88 sob a marca da heterogeneidade. Não havia, propriamente, uma interseção sistêmica verdadeiramente estruturada, à exceção do paradigma procedimental de legalidade, cuja inspiração adveio dos protocolos inspecionais. Fora isso, o que se desenvolviam, eventualmente, eram mecanismos mais ou menos sofisticados de amortecimento de tensões entre Relações de Trabalho e Inspeção do Trabalho, cujo desempenho dependia de certos atributos pessoais dos Fiscais do Trabalho envolvidos nessas interações.

Mas a expectativa geral é a que a fronteira entre Relações de Trabalho e Inspeção do Trabalho fosse mesmo tensionada. De um lado, a aproximação com as entidades de representação classista, de outro, o isolamento institucional e a purificação da narrativa inspecional. De um lado, o paradigma patrimonial-restitutivo e saneador, de outro, a 
vigilância e o controle. De um lado, a flexibilização procedimental, de outro, a rigidez dos protocolos remotamente controlados. De um lado, a possibilidade de punição como instrumento de "coerciliação", de outro, o dever de punir, a despeito do eventual caráter restaurativo (relacional) da composição patrimonial.

Essas experiências, contudo, podem se submeter a tensões ainda mais agudas, uma vez que os mecanismos de amortecimento, de base relacional, dependem, modo geral, da solidariedade funcional e identitária entre Fiscais do Trabalho. O Sistema de Relações de Trabalho, por seu turno, consegue operar sem a presença e a atuação de AFTs em seu interior. Desse modo, sobretudo a partir do processo de esvaziamento da participação de AFTs no modelo de mediação em Mesa-redonda, é de se esperar que aqueles mecanismos passem a não funcionar corretamente. Nesse sentido, a única alternativa, considerando a necessidade de distencionar as operações da Inspeção e do Sistema de Relações de Trabalho, era mesmo a de redução do escopo de atuação das Mesas-redondas, que tratariam quase que exclusivamente dos conflitos coletivos de interesses.

Mesmo nesse caso, é de se indagar sobre o fundamento de atuação da mediação em Mesa-redonda, considerando o contexto de desempoderamento das representações sindicais de categorias profissionais. Essa reflexão é importante, porque todo o processo de construção de conteúdo, de formação e de qualificação de mediadores, desenvolvido no âmbito do extinto MTb durante os anos 90 e a última década, se deu a partir da premissa do impasse, enquanto elemento de ignição da iniciativa mediadora.

Ocorre que o impasse não é o único episódio que dispara a iniciativa da mediação. Há, também, a autopercepção, por qualquer sujeito coletivo, de sua incapacidade para atrair sujeitos outros para a negociação, ou acessar os espaços negociais, ou, mesmo acessando-os, de fazê-lo em condições de exercer o autêntico direito de deliberação, ou seja, de discutir, de boa-fé e em pé de igualdade, uma determinada pauta de reivindicações.

A abrupta desidratação financeira do sistema sindical brasileiro, a exaltação dos pactos individuais, as áreas de exclusão sindical, mesmo no âmbito da representação de interesses laborais coletivos, o silenciamento da deliberação categorial em nome da coletivização das escolhas individuais; tudo, enfim, conspira a favor de uma crise sem precedentes da autonomia negocial coletiva dos sindicatos profissionais, o que se reflete na redução acentuada (e generalizada) dos processos administrativos de mediação de conflitos trabalhistas em Mesas-redondas e mesmo dos instrumentos normativos registrados. ${ }^{19}$

\footnotetext{
${ }^{19}$ Considerando apenas a Gerência Regional do Trabalho de Volta Redonda, reconhecidamente uma referência nacional em mediação de conflitos trabalhistas (ASSUMPÇÃO, 2016), entre 2009 e 2019, houve uma redução de 94,3\% no número de processos protocolados de Mesas-redondas.
} 
Projeções para um modelo de adjudicação administrativa de conflitos nas relações laborais no pósreforma trabalhista e pós-extinção do Ministério do Trabalho

Embora se constatem os sintomas, não se reclama, apenas, um único diagnóstico para o problema. Decerto que o encolhimento da estrutura do Sistema de Relações de Trabalho não seria responsável, sozinho, pelo frustrante desempenho da mediação em Mesas-redondas. No âmbito dos conflitos individuais, a extinção da assistência homologatória e o advento do distrato, como hipótese terminativa do contrato de trabalho, ajudam a explicar a virtual extinção das mediações baseadas em direitos rescisórios, uma vez que se transfere, para o âmbito intramuros da empresa e de seus prepostos, o espaço consensual que antes era público.

Mas o que dizer dos conflitos coletivos?

O fastio negocial das representações patronais e a redução da capacidade de mobilização e de barganha dos sindicatos voltam a ser os suspeitos preferenciais, desde o advento da Emenda Constitucional $\mathrm{n}^{\circ} 45$ e seu dissídio coletivo consensual (ASSUMPÇÃO, 2016).

Se a suspeita procede, como deverá ser, então, o modelo de mediação pública de conflitos coletivos? Tenderá a ser interventivo, revertendo o receituário da democracia nas relações de trabalho? Será marcadamente orientado a equilibrar a balança negocial em favor das representações de trabalhadores? Ou será uma espécie de "chancelaria político-jurídica”, vocacionada a realizar o controle/legitimação legal dos interesses patronais, resgatando a tradição do extinto Conselho Nacional do Trabalho dos anos 20? Deverá consagrar formalmente outras (e novas) estruturas de representação coletiva de trabalhadores, como as "comissões de fábrica"? Contemplará os conflitos de interesses e direitos de empregados e servidores públicos? Tornar-se-á uma instância arbitral?

Boa parte das respostas, senão todas, dependerão do tipo de compromisso institucionalizado pelo Estado regulador. Sendo assim, uma hipótese que concilie um modelo econômico ultraliberal, sustentado à custa de um indisfarçável déficit democrático, com o paradigma da hipossuficiência do sujeito-trabalhador e da proteção jurídica das categorias profissionais, parece-nos bem mais que improvável.

Nesse sentido, não é necessário sequer avançar pela crítica da desconstrução do Estado Social, bastando apontar a inconciliabilidade radical entre a legitimidade sindical para a ação coletiva, e do Estado interventor nas wage-relations (JESSOP, 2008), com os princípios da doutrina ultraliberal, justamente porque os protagonismos do Estado e do movimento sindical desorientam a ação pan-reguladora do mercado.

Nesse contexto, é possível especular sobre um modelo de adjudicação públicoadministrativa de conflitos trabalhistas, a partir de determinados parâmetros:

a) ressignificação do conflito trabalhista como um "conflito de classes", que seria deslocado do seu sentido histórico e estruturante da relação capital x trabalho; 
b) experimentação do tratamento atomizado dos conflitos de direitos, a partir do conceito de "governo digital", referenciado no paradigma consumerista;

c) priorização das negociações entre empresas e sindicatos, visando aos acordos coletivos, em virtude do princípio da especificidade (art. 620, CLT), elevado a critério hegemônico de solução de antinomias normativas;

d) incorporação das "negociações coletivizadas" ou negociações individuais plúrimas, que contemplariam pautas de interesses de empresas, grupos econômicos ou setores produtivos, à revelia das representações sindicais como articuladores orgânicos dos interesses categoriais;

e) no rastro do item anterior, a Mesa-redonda se torna o espaço de contratação coletiva, possibilitando que novas formas organizativas, com ou sem caráter associativo, sejam incorporadas ao rol de sujeitos legitimados para requerer a mediação;

f) no âmbito dos conflitos de direitos, sobretudo os coletivos, o estabelecimento de vínculos formais, parciais e seletivos com a fiscalização trabalhista;

g) orientação teleológica para o arrefecimento da autotutela operária, a higidez da empresa e a liberdade econômica;

h) domínio absoluto do paradigma do impasse;

i) incorporação do conflito de legalidade/constitucionalidade das cláusulas de acordo ou convenção coletiva e, com isso, da funcionalidade legitimadora a priori dos dispositivos autonormativos;

j) pactos patrimoniais com efeito autoexecutório;

Mas o desenho que aqui se especula não pode ser tomado como algo inevitável, sequer factível, pois os parâmetros elencados consistem em possibilidades que contemplam apenas um lado da equação: o conjunto de compromissos institucionalizados que emerge do novo contexto político e da atual orientação da ordem econômica, que, como dissemos, determina, também, os rumos da ordem social.

Embora se possa pensar num modelo de adjudicação de conflitos trabalhistas, enquanto política pública formulada a partir desse novo conjunto de compromissos institucionalizados, a interação dos diversos estratos que compõem a estrutura da máquina estatal, com suas diversas formas regulatórias e seus múltiplos agentes, criam um hiato entre a decisão política e a implementação do modelo que é difícil de mensurar.

Seja devido às tensões com a Inspeção do Trabalho, ao télos protetivo ou ao tradicional perfil comunitarista, o modelo de adjudicação administrativa de conflitos trabalhistas, seja ele qual for, dificilmente conseguirá operar Brasil afora de maneira linear e homogênea. Nesse sentido, as soluções pactuadas em Mesas-redondas tenderão a 
Projeções para um modelo de adjudicação administrativa de conflitos nas relações laborais no pósreforma trabalhista e pós-extinção do Ministério do Trabalho

seguir indóceis em relação ao algoritmo binário do direito, customizadas, que sempre foram, segundo o princípio satisfativo de ambos os sujeitos em conflito.

\section{OLHANDO PARA TRÁS PARA ENXERGAR OS OBSTÁCULOS À FRENTE}

Reprisando o que foi dito linhas atrás, ao estatuto normativo aberto se credita, em grande parte, a heterogeneidade e as tensões que caracterizaram o modelo de mediação pública de conflitos trabalhistas, no âmbito do extinto MTb. Entre tantas, as fricções internas com a Inspeção do Trabalho sempre se mostraram as mais importantes, entre outras razões porque coube ao sistema inspecional delegar ao Sistema de Relações de Trabalho o paradigma de legalidade procedimental, que definiu os processos adjudicatórios de conflitos trabalhistas, mormente os de natureza jurídica.

Mas é equívoco limitar às interações intersistêmicas: Inspeção e Relações de Trabalho, a origem de todas as disfuncionalidades do modelo de mediação pública de conflitos trabalhistas. Existem, de fato, vários e diversificados fatores, internos e externos (interinstitucionais) que, ao longo dos anos 90 e da última década, comprometeram o desempenho das Mesas-redondas. Tais fatores podem ser vistos no quadro a seguir, aos quais se relacionam as perturbações impostas ao modelo, bem como as possibilidades correspondentes de superação.

Assim temos:

Quadro 1 - Mediação Público-Administrativa de Conflitos Trabalhistas: fragilidades e possibilidades

\begin{tabular}{|c|c|c|}
\hline $\begin{array}{l}\text { ORIGEM DO } \\
\text { PROBLEMA }\end{array}$ & $\begin{array}{l}\text { DESCRIÇÃO DO } \\
\text { PROBLEMA }\end{array}$ & $\begin{array}{l}\text { POSSIBILIDADE DE } \\
\text { SOLUCุÃO }\end{array}$ \\
\hline $\begin{array}{l}\text { Interação com a Inspeção } \\
\text { do Trabalho }\end{array}$ & $\begin{array}{l}\text { A questão da abordagem: } \\
\text { vigilância, controle e } \\
\text { punição x restituição } \\
\text { patrimonial mediante } \\
\text { consenso formal. } \\
\text { Esvaziamento funcional da } \\
\text { Inspeção do Trabalho: } \\
\text { comprometimento do } \\
\text { quadro e o problema das } \\
\text { metas. } \\
\text { A questão do objeto: } \\
\text { ordenamento jurídico } \\
\text { (normativismo dogmático) } \\
\text { x patrimônio jurídico- } \\
\text { econômico do trabalhador } \\
\text { (operariocentrismo). } \\
\text { A questão dos vínculos: a) }\end{array}$ & $\begin{array}{l}\text { Reintrodução do } \\
\text { paradigma restitutivo na } \\
\text { política inspecional. } \\
\text { Estabelecimento de } \\
\text { vínculos formais } \\
\text { coordenativos entre a } \\
\text { Inspeção do Trabalho e o } \\
\text { Sistema de Relações de } \\
\text { Trabalho, no que se refere } \\
\text { aos resultados obtidos em } \\
\text { Mesa-redonda, em sede de } \\
\text { conflitos de direitos; } \\
\text { Estabelecimento de } \\
\text { vínculos instrumentais } \\
\text { (convolações, apropriações } \\
\text { ou processos sincréticos) } \\
\text { entre os Procedimentos }\end{array}$ \\
\hline
\end{tabular}

R. Opin. Jur., Fortaleza, ano 19, n. 31, p.96-126, maio/ago. 2021 


\begin{tabular}{|c|c|c|}
\hline & $\begin{array}{l}\text { relação acordo x punição; } \\
\text { b) abonação narrativa a } \\
\text { priori e compartilhamento } \\
\text { cognitivo e informacional; } \\
\text { c) paradigma de legalidade; } \\
\text { d) apropriação dos } \\
\text { resultados concretos. } \\
\text { A questão da } \\
\text { "redundância”: Mesa- } \\
\text { redonda x Procedimento } \\
\text { Especial. } \\
\text { A questão da "autoridade”: } \\
\text { AFT x Agentes } \\
\text { Administrativos. }\end{array}$ & $\begin{array}{l}\text { Especiais (Mesas de } \\
\text { Entendimento), as ações } \\
\text { fiscais diretas ou indiretas } \\
\text { e as Mesas-redondas. } \\
\text { Adaptação dos sistemas } \\
\text { (SFIT e } \\
\text { SIRT/MEDIADOR), a fim } \\
\text { de acomodar os resultados } \\
\text { e as transitividades entre a } \\
\text { Inspeção e o Sistema de } \\
\text { Relações de Trabalho). } \\
\text { Reconhecimento da } \\
\text { autoridade do "Presidente } \\
\text { da Mesa-redonda”, no que } \\
\text { se refere à administração } \\
\text { da mediação, inclusive } \\
\text { quanto à instrução } \\
\text { processual nos conflitos de } \\
\text { direitos. } \\
\text { Reconhecimento do } \\
\text { espaço da mediação } \\
\text { também como um lugar de } \\
\text { construção de diagnósticos } \\
\text { e narrativas válidas para a } \\
\text { ação fiscal, sem embargo } \\
\text { da autotutela fático- } \\
\text { jurídica produzida pela } \\
\text { Inspeção do Trabalho, no } \\
\text { âmbito de sua } \\
\text { competência. }\end{array}$ \\
\hline Estrutura & $\begin{array}{l}\text { O problema dos conflitos } \\
\text { individuais. }\end{array}$ & $\begin{array}{l}\text { Utilização de protocolos } \\
\text { do "governo digital". } \\
\text { Possibilidade de convênios } \\
\text { com universidades, com a } \\
\text { OAB e com sindicatos. }\end{array}$ \\
\hline Do quadro funcional & $\begin{array}{l}\text { Quanto aos AFTs, o } \\
\text { quadro reduzido; quanto } \\
\text { aos Agentes } \\
\text { Administrativos, a } \\
\text { ausência de contrapartidas } \\
\text { e/ou de novas } \\
\text { denominações funcionais. }\end{array}$ & $\begin{array}{l}\text { Possibilidade de inserção } \\
\text { de AFTs no Sistema de } \\
\text { Relações de Trabalho, } \\
\text { inclusive em postos de } \\
\text { chefia e coordenação, uma } \\
\text { vez que os novos vínculos } \\
\text { formados permitirão o } \\
\text { compartilhamento de } \\
\text { resultados apreciáveis por } \\
\text { ambos os sistemas. No }\end{array}$ \\
\hline
\end{tabular}


Projeções para um modelo de adjudicação administrativa de conflitos nas relações laborais no pósreforma trabalhista e pós-extinção do Ministério do Trabalho

\begin{tabular}{|c|c|c|}
\hline & & $\begin{array}{l}\text { âmbito dos conflitos de } \\
\text { direitos, o protocolo } \\
\text { restitutivo aplicado às } \\
\text { mediações individuais ou } \\
\text { coletivas serviria tanto para } \\
\text { as metas da Inspeção do } \\
\text { Trabalho quanto para o } \\
\text { Sistema de Relações de } \\
\text { Trabalho. } \\
\text { Possibilidade de criação de } \\
\text { incentivos ao quadro } \\
\text { administrativo a serviço do } \\
\text { modelo de mediação, seja } \\
\text { por meio da criação de um } \\
\text { novo quadro, seja por } \\
\text { meio de gratificações } \\
\text { vinculadas à função ou à } \\
\text { qualificação. }\end{array}$ \\
\hline $\begin{array}{l}\text { Da administração dos } \\
\text { resultados }\end{array}$ & $\begin{array}{l}\text { Nos conflitos baseados em } \\
\text { interesses, a falácia do } \\
\text { "acordo em Mesa- } \\
\text { redonda". }\end{array}$ & $\begin{array}{l}\text { Aperfeiçoamento do } \\
\text { Sistema Mediador, no } \\
\text { sentido de introduzir } \\
\text { outros resultados } \\
\text { intermediários } \\
\text { (sobrestamento, acordo } \\
\text { parcial, consenso sujeito } \\
\text { ao referendo ou } \\
\text { referendado em assembleia } \\
\text { etc.), de preferência em } \\
\text { sincronia com os } \\
\text { procedimentos de } \\
\text { depósito, registro e } \\
\text { arquivamento de } \\
\text { instrumentos normativos. }\end{array}$ \\
\hline $\begin{array}{l}\text { Dos vínculos } \\
\text { interinstitucionais, no } \\
\text { âmbito dos conflitos de } \\
\text { direitos }\end{array}$ & $\begin{array}{l}\text { O patrulhamento } \\
\text { metodológico do MPT. } \\
\text { O caráter homologatório. } \\
\text { O problema da } \\
\text { autoexecutividade judicial. }\end{array}$ & $\begin{array}{l}\text { Modificação normativa, } \\
\text { introduzindo na própria } \\
\text { CLT certas previsões, tais } \\
\text { como: } \\
\text { a) à semelhança dos } \\
\text { processos individuais de } \\
\text { anotação de CTPS (arts. } \\
36 \text { a 39) pode-se introduzir } \\
\text { um protocolo de mediação } \\
\text { preventiva ou saneadora, } \\
\text { especificamente quanto às } \\
\text { verbas rescisórias; }\end{array}$ \\
\hline
\end{tabular}




\begin{tabular}{|c|c|c|}
\hline & & $\begin{array}{l}\text { b) expressa menção às } \\
\text { Mesas-redondas no } \\
\text { capítulo IV do Título X da } \\
\text { CLT, destinado aos } \\
\text { dissídios coletivos; } \\
\text { c) inclusão do acordo em } \\
\text { Mesa-redonda e em } \\
\text { procedimento especial no } \\
\text { rol de títulos executivos } \\
\text { extrajudiciais, disposto no } \\
\text { art. 876, CLT; } \\
\text { d) possibilidade de menção } \\
\text { às Mesas-redondas no } \\
\text { Título VI da CLT, que } \\
\text { trata das negociações } \\
\text { coletivas; } \\
\text { e) no mesmo título, } \\
\text { menção expressa aos } \\
\text { instrumentos normativos } \\
\text { de "efeitos concretos”, } \\
\text { voltados aos acordos } \\
\text { coletivos de restituição } \\
\text { patrimonial. }\end{array}$ \\
\hline Da regulamentação & $\begin{array}{l}\text { Padronização e controle x } \\
\text { simplicidade e } \\
\text { adaptabilidade. }\end{array}$ & $\begin{array}{l}\text { Edição de uma nova } \\
\text { portaria (talvez conjunta, } \\
\text { SIT e SRT), em } \\
\text { substituição à de no } \\
\text { 3.122/88, regulamentando } \\
\text { as Mesas-redondas de } \\
\text { forma um pouco mais } \\
\text { refinada, sem, contudo, } \\
\text { asfixiá-la } \\
\text { procedimentalmente, na } \\
\text { qual se distinguiriam: } \\
\text { a) os tipos de conflitos } \\
\text { (direitos e interesses); } \\
\text { b) as modalidades de } \\
\text { protocolo interventivo } \\
\text { (mediação, conciliação e } \\
\text { arbitragem); } \\
\text { c) os titulares da pretensão } \\
\text { mediadora (incluindo os } \\
\text { trabalhadores, omissão } \\
\text { inexplicável da Portaria no }\end{array}$ \\
\hline
\end{tabular}


Projeções para um modelo de adjudicação administrativa de conflitos nas relações laborais no pósreforma trabalhista e pós-extinção do Ministério do Trabalho

\begin{tabular}{|c|c|c|}
\hline & & $\begin{array}{l}\text { 3.122/88); } \\
\text { d) as conexões com o } \\
\text { Sistema de Inspeção do } \\
\text { Trabalho; } \\
\text { e) procedimentos junto ao } \\
\text { Sistema Mediador e, } \\
\text { eventualmente, ao SFIT; } \\
\text { f) prerrogativas do } \\
\text { mediador; } \\
\text { g) expressa menção à lei } \\
\text { 9.784/99 (Processo } \\
\text { Administrativo Federal), } \\
\text { como norma supletiva. }\end{array}$ \\
\hline $\begin{array}{l}\text { Da ambiguidade dos perfis } \\
\text { atribuídos ao "mediador" }\end{array}$ & $\begin{array}{l}\text { Convite ou convocação? } \\
\text { Conciliação, "coerciliação" } \\
\text { ou arbitragem mitigada? }\end{array}$ & $\begin{array}{l}\text { Com base na nova } \\
\text { portaria, esses perfis } \\
\text { ficariam sugeridos ou } \\
\text { definidos de acordo com o } \\
\text { objeto do conflito e o tipo } \\
\text { processual, isto é, com o } \\
\text { interesse qualificado do } \\
\text { Estado no caso concreto. } \\
\text { Com relação à arbitragem, } \\
\text { o perfil do terceiro } \\
\text { imparcial seria definido } \\
\text { por regulamentação } \\
\text { específica, inclusive quanto } \\
\text { às possibilidades de } \\
\text { convolação e } \\
\text { instrumentalização do } \\
\text { processo de mediação. }\end{array}$ \\
\hline $\begin{array}{l}\text { O desenvolvimento de } \\
\text { mediadores }\end{array}$ & $\begin{array}{l}\text { A mediação como técnica } \\
\text { e como vocação; } \\
\text { O domínio da Escola } \\
\text { Tradicional-Linear. }\end{array}$ & $\begin{array}{l}\text { Programas de qualificação } \\
\text { centrados na Escola } \\
\text { Tradicional-Linear e na } \\
\text { Escola Transformativa. } \\
\text { Programas de qualificação } \\
\text { em parceria com centros } \\
\text { de reconhecida excelência } \\
\text { (DIEESE, Mediare, CNJ } \\
\text { etc.). } \\
\text { Criação de programas de } \\
\text { formação e } \\
\text { aperfeiçoamento por meio } \\
\text { da ENIT, incluindo } \\
\text { convênios com programas }\end{array}$ \\
\hline
\end{tabular}




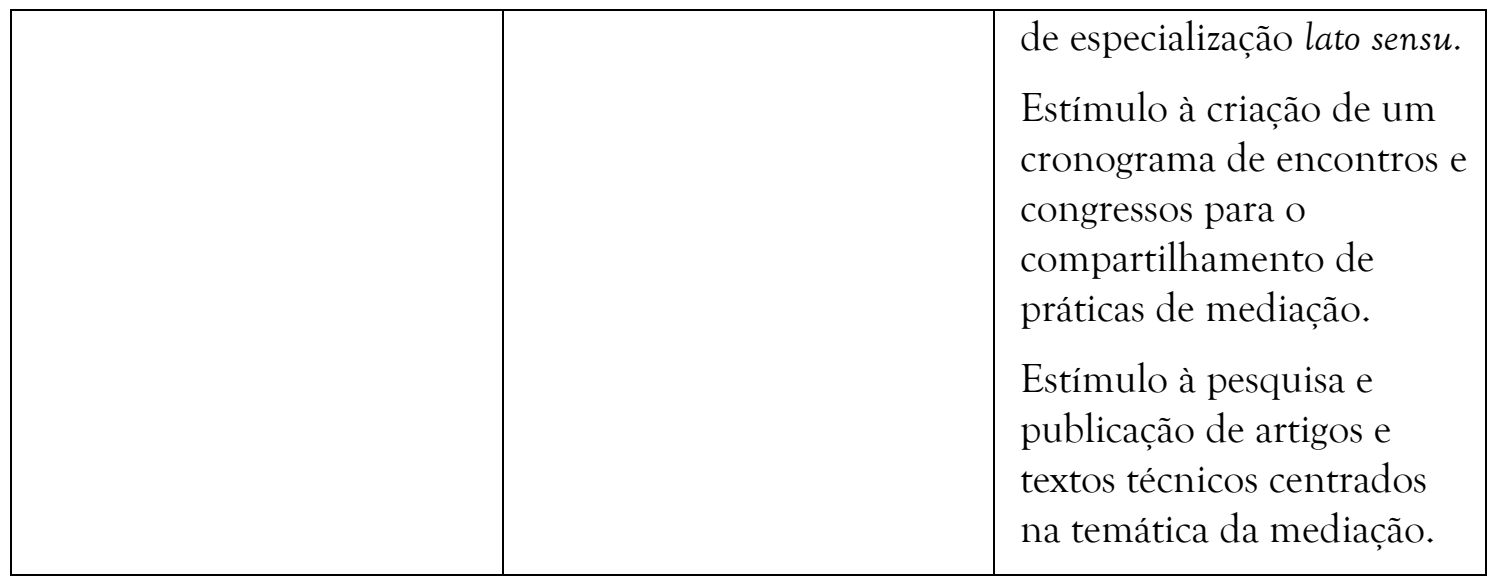

Fonte: elaborado pelo autor.

É desse modo que se vislumbra o horizonte à frente e toda a complexidade do empreendimento de (re)construção de um modelo de adjudicação públicoadministrativa de conflitos trabalhistas. Ademais, a respeito de um contexto político e econômico atual, tendente a retirar o debate social do espaço público, há uma série de entraves intrínsecos e extrínsecos do tradicional modelo administrativo-processual das Mesas-redondas que precisam ser enfrentados, não sem a convergência, todavia, de outras formas institucionais identificadas com a proteção do trabalhador brasileiro.

\section{CONSIDERAÇÕES FINAIS}

Desde a publicação da Portaria 3.122/88, o modelo de adjudicação administrativa de conflitos trabalhistas, denominado mediação em Mesa-redonda, constituiu-se numa forma híbrida de ação interventiva do Estado. A despeito de sua aderência ao Sistema de Relações de Trabalho, a integração das ações mediadoras ao rol de atributos da Inspeção do Trabalho jamais foi desprezível. Ao contrário, pode-se afirmar que a mediação administrativa de conflitos e a fiscalização trabalhista, durante as duas primeiras décadas da promulgação da CRFB/88, eram expressões de uma única forma institucional de intervenção estatal nas wage-relations.

Mas o modelo de mediação de conflitos operado pelo então Ministério do Trabalho, ainda que com erros e acertos, buscava atender às promessas constitucionais relativas à ordem social, seja de acesso à justiça e cidadania salarial, seja de democratização das relações de trabalho. Com a reforma trabalhista, seguida da extinção do próprio $\mathrm{MTb}$, surge a necessidade de se indagar sobre a utilidade de um modelo de solução de conflitos trabalhistas, uma vez que tanto o paradigma de acesso à justiça e de cidadania salarial quanto o da representatividade coletiva de interesses da classe trabalhadora estão fortemente comprometidos pelo princípio hegemônico da liberdade econômica. 
Projeções para um modelo de adjudicação administrativa de conflitos nas relações laborais no pósreforma trabalhista e pós-extinção do Ministério do Trabalho

Sendo assim, é pouco provável que um modelo de adjudicação de conflitos trabalhistas, reorganizado no âmbito do Ministério da Economia, se oriente pelo vetor protetivo do trabalhador ou mesmo enfatize o poder-dever da representatividade sindical, pois tanto a ideia de um estatuto de proteção social quanto o exercício coletivo do direito de resistência operária são vistos, conforme a ótica ultraliberal, como ameaças à capacidade regulatória do mercado.

\section{REFERÊNCIAS}

ALMEIDA, Denise Coelho de. Arbitragem nos Dissídios Individuais Trabalhistas. Nómadas. Revista Crítica de Ciencias Sociales y Jurídicas, Madrid, n. 17, 2008. Disponível em: http://www.theoria.eu/nomadas/17/denisecoelho_arbitragem.pdf. Acesso em: 18 fev. 2020.

ASSUMPÇÃO, L. F. Primeiras Linhas Sobre a Mediação Pública de Conflitos Trabalhistas no Brasil: descortinando as Mesas Redondas. In: CONGRESSO INTERNACIONAL INTERDISCIPLINAR EM SOCIAIS E HUMANIDADES (I CONINTER), 2012, Niterói. Anais [...]. Niterói: Eduff, 2012.

ASSUMPÇÃO, L. F. As Mesas Redondas e o Cumprimento Negociado da NR 12: uma experiência de integração entre os sistemas de Inspeção do Trabalho e Relações de Trabalho, no âmbito do Ministério do Trabalho e Emprego. In: MEIRELLES, Delton Ricardo Soares et al. (org.). Mediação extrajudicial e justiça restaurativa. Niterói: PPGSD - Programa de Pós-Graduação em Sociologia e Direito, 2013. v. I, p. 61-79.

ASSUMPÇÃO, L. F. A Mediação de Conflitos de Direitos no Âmbito do Ministério do Trabalho e Emprego: entre paradigmas e paradoxos. In: CONGRESSO DA ABRASD, 5., 2014, Vitória. Anais [...]. Porto Alegre: ABraSD, 2014. v. 1. p. 1469-1495.

ASSUMPÇÃO, L. F. A Inspeção do trabalho, as Relações de Trabalho e o Problema da Integração Intersistêmica: ou a asfixia da mediação de conflitos de direito no âmbito do Ministério do Trabalho e Emprego. In: CONGRESSO INTERNACIONAL INTERDISCIPLINAR EM SOCIAIS E HUMANIDADES, 4., 2015, Foz do Iguaçu. Anais [...]. Foz do Iguaçu, 2015. v. 24. p. 25-49.

ASSUMPÇÃO, L. F. O Sistema, a História, a Política e o Futuro da Inspeção do Trabalho no Brasil. 2018. 451 f. Tese (Doutorado em Ciências Jurídicas e Sociais) Universidade Federal Fluminense, Niterói, 2018.

ASSUMPÇÃO, L. F. Monsores de. Dissídio Coletivo Consensual e Autonomia Negocial Coletiva: uma análise teórica e empírica dos paradoxos e determinismos da "crise" do sindicalismo brasileiro. Rio de Janeiro: Lumen Juris, 2016. v. 1. 
ASSUMPÇÃO, L. F. Alguns Prognósticos sobre o Futuro das Relações de Trabalho e da Inspeção do Trabalho no Brasil após a "Reforma Trabalhista" (Lei n. 13.467/2017). In: SILVA FILHO, Carlos Fernando da; JORGE, Rosa Maria Campos; RASSY, Rosângela Silva (org.). Reforma Trabalhista: uma reflexão dos Auditores-Fiscais do Trabalho sobre os efeitos da Lei n. 13.467/2017 para os trabalhadores. São Paulo: LTr, 2019a. v. 1, p. $15-27$.

ASSUMPÇÃO, L. F. A resiliência da inspeção do trabalho brasileira: estratégias de reconfiguração (ou desfiguração?) no pós- Constituição de 88. Revista Teoria Jurídica Contemporânea, Rio de Janeiro, v. 1, n. 1, p. 206-245, 2019 b.

BASTAZINE, Cleber Alves. Mediação em Relações Individuais de Trabalho. 2012. 181 f. Dissertação (Mestrado em Direito) - Universidade do Estado de São Paulo, São Paulo, 2012.

BOITO JÚNIOR, Armando. Neoliberalismo e corporativismo de Estado no Brasil. In: ARAÚJO, Ângela (org.). Do corporativismo ao neoliberalismo: Estado e trabalhadores no Brasil e na Inglaterra. São Paulo: Boitempo, 2002. p. 59-87.

BOITO JÚNIOR, Armando. Hegemonia neoliberal no governo Lula. CEMARX Crítica Marxista, Rio de Janeiro, n. 17, 2003. Disponível em: http://biblioteca.clacso.edu.ar/ar/libros/brasil/unicamp/Governo_Lula.pdf. Acesso em: 25 fev. 2019.

BRASIL. Constituição (1988). Constituição da República Federativa do Brasil de 1988. Brasília, DF: Presidência da República, 1988. Disponível em: http://www.planalto.gov.br/ccivil_03/constituicao/constituicao.htm. Acesso em: 25 jul. 2018.

BRASIL. Ministério do Trabalho. Portaria MTb no 3.122 de 05 de julho de 1988. Dispõe sobre a composição dos conflitos individuais e coletivos de trabalho. Brasília, DF: Presidência da República, 1988. Disponível em: https://www.legisweb.com.br/legislacao/?id=181160. Acesso em: 7 jan. 2020.

BRASIL. CLT. Decreto-Lei $\mathbf{n}^{\circ} \mathbf{5 . 4 5 2}$, de $\mathbf{1}^{\circ}$ de maio de 1943. Aprova a Consolidação das Leis do Trabalho. Brasília, DF: Presidência da República, 1943. Disponível em: http://www.planalto.gov.br/ccivil_03/decretolei/Del5452compilado.htm. Acesso em: 25 nov. 2019.

BRASIL. Decreto-Lei no 229 de 28 de fevereiro de 1967. Altera dispositivos da Consolidação das Leis do Trabalho, aprovada pelo Decreto-lei no 5.452, de $1^{\circ}$ de maio de 1943, e dá outras providencias. Brasília, DF: Presidência da República, 1967. Disponível em: http://www.planalto.gov.br/ccivil_03/decreto-lei/Del0229.htm. Acesso em: 7 jan. 2020. 
Projeções para um modelo de adjudicação administrativa de conflitos nas relações laborais no pósreforma trabalhista e pós-extinção do Ministério do Trabalho

BRASIL. Ministério do Trabalho e Emprego. Portaria MTE no 160 de 13 de abril de 2004. Dispõe sobre o desconto em folha de pagamento das contribuições instituídas pelos sindicatos. Brasília, DF: Presidência da República, 2004. Disponível em: http://www.guiatrabalhista.com.br/legislacao/port160.htm. Acesso em: 7 jan. 2020.

BRASIL. Portaria $\mathrm{n}^{\circ} 546$ de 12 de março de 2010. Disciplina a forma de atuação da Inspeção do Trabalho, a elaboração do planejamento da fiscalização, a avaliação de desempenho funcional dos Auditores Fiscais do Trabalho, e dá outras providências. Disponível em: http://www.normaslegais.com.br/legislacao/portariamte546_2010.htm. Acesso em: 19 fev. 2020.

BRASIL. Conselho Nacional de Justiça. Guia de Conciliação e Mediação Judicial: orientação para instalação de CEJUSC. Brasília, DF: Conselho Nacional de Justiça, $2015 . \quad$ Disponivel em: https://www.cnj.jus.br/wpcontent/uploads/2015/06/1818cc2847ca50273fd110eafdb8ed05.pdf. Acesso em: 19 fev. 2020.

BRASIL. Portaria n $^{\circ} 643$ de 11 de maio de 2016. Disciplina a forma de atuação da Inspeção do Trabalho, a elaboração do planejamento da fiscalização, a avaliação de desempenho funcional dos Auditores Fiscais do Trabalho, e dá outras providências. Disponivel em: http://www.in.gov.br/materia//asset_publisher/KujrwOTZC2Mb/content/id/22906361/do1-2016-05-13-portaria-n643-de-11-de-maio-de-2016-22906290. Acesso em: 19 fev. 2020.

BRASIL. Lei $\mathbf{n}^{\circ} 13.467$ de 13 de julho de 2017. Altera a Consolidação das Leis do Trabalho (CLT), aprovada pelo Decreto-Lei no 5.452 , de $1^{\circ}$ de maio de 1943, e as Leis $\mathrm{n}^{\circ}$ 6.019, de 3 de janeiro de 1974, 8.036, de 11 de maio de 1990, e 8.212, de 24 de julho de 1991, a fim de adequar a legislação às novas relações de trabalho. Brasília, DF: Presidência da República, 2017. Disponível em: http://www.planalto.gov.br/ccivil_03/_ato2015-2018/2017/lei/L13467.htm. Acesso em: 7 jan. 2020.

CAMILO, Denise Corassa. Comissões de Conciliação Prévia: agilizar ou desregulamentar? 2008. 128 f. Dissertação (Mestrado em Desenvolvimento Econômico) - UNICAMP, Campinas, 2008.

CESARINO JÚNIOR, A. F. Direito Corporativo e Direito do Trabalho: soluções práticas. São Paulo: Livraria Martins Editora, 1940.

DALlEGRAVE NETO, José Affonso; GARCIA, Phelippe H. Cordeiro. Arbitragem em Dissídios Individuais de Trabalho. Revista eletrônica do Tribunal Regional do Trabalho da 9a Região, Curitiba, v. 8, n. 73, p. 26-42, nov. 2018. Disponível em: https://juslaboris.tst.jus.br/bitstream/handle/20.500.12178/149832/2018_dallegrave_ neto_jose_arbitragem_dissidios.pdf?sequence=1\&isAllowed=y. Acesso em: 17 fev. 2020. 
GEORGE, Henry. The Condition of Labor: an Open Letter to Pope Leo XIII (1891). New York: United States Book Company, 1891. Disponível em: http://archive.org/details/conditionoflabor00georuoft. Acesso em: 19 fev. 2012.

GIDDENS, Anthony. As Consequências da Modernidade. São Paulo: Ed. UNESP, 1991.

GUNTHER, Luiz Eduardo; PIMPÃO, Rosemarie D. (coord.). Conciliação: um caminho para a paz social. Curitiba: Juruá, 2013.

HILLESHEIM, Jaime. Conciliação Trabalhista: ofensiva sobre os direitos dos trabalhadores na periferia do capitalismo. 2015. 695 f. Tese (Doutorado em Serviço Social) - Universidade Federal de Santa Catarina, Florianópolis, 2015.

JAZZAR, Inês Sleiman Molina. Mediação e Conflitos Coletivos de Trabalho. 2008. 218 f. Dissertação (Mestrado em Direito) - Universidade do Estado de São Paulo, São Paulo, 2008.

JESSOP, B. El Futuro del Estado Capitalista. Madrid: Los Libros de la Catarata, 2008.

MAGANO, Octávio Bueno. Arbitragem. Revista da Faculdade de Direito da USP, São Paulo, v. 1, n. 1, p. 31-40, 1986.

MATTOS NETO, Antônio José. Direitos Patrimoniais Disponíveis e Indisponíveis à Luz da Lei da Arbitragem. In: FRANCO FILHO, Georgenor de Sousa (coord.). Temas Atuais de Direito. [S.l.: s.n.], 2013. p. 49-62.

MOHALLEM, Ricardo Antônio. Comissões de Conciliação Prévia. Revista do Tribunal Regional do Trabalho da 3a Região, Belo Horizonte, v. 31, n. 61, p. 41-73, jan./jun. 2000.

NASSIF, Elaine Noronha. Conciliação Judicial e Devido Processo Legal. De jure: Revista Jurídica do Ministério Público do Estado de Minas Gerais, Belo Horizonte, n. 12, p. 231-241, jan./jun. 2009.

OLIVA, José R. Dantas. Comissões de Conciliação Prévia: submissão obrigatória afronta o princípio da inafastabilidade do controle constitucional - comentário a acórdão. Revista do Tribunal Regional do Trabalho da 15ª Região, Campinas, n. 18, p. 77-89, mar. 2002.

PAMPLONA FILHO, Rodolfo. Atualizando uma visão didática da arbitragem na área trabalhista. Revista Jus Navigandi, Teresina, n. 700, 5 jun. 2005. Disponível em: https://jus.com.br/artigos/6831. Acesso em: 18 fev. 2020.

SADER, Emir; GENTILI, Pablo (org.). Pós-neoliberalismo: as políticas sociais e o Estado democrático. São Paulo: Paz e Terra, 1995. 
Projeções para um modelo de adjudicação administrativa de conflitos nas relações laborais no pósreforma trabalhista e pós-extinção do Ministério do Trabalho

SADER, Emir (org.). 10 anos de governos pós-neoliberais no Brasil: Lula e Dilma. São Paulo: Boitempo; Rio de Janeiro: FLACSO Brasil, 2013.

SILVA, Sayonara Grillo C. L. da. Relações Coletivas de Trabalho: configurações institucionais no Brasil Contemporâneo. São Paulo: LTr, 2008.

SILVA, Sayonara Grillo C. L. da. Mudanças Normativas e Sindicalismo Transformações Recentes. Revista LTr Legislação do trabalho, São Paulo, v. 75, n. 9, p. 1041-1052, set. 2011.

SHMITTER, Philippe. Still the Century of Corporatism? In: STRITCH, Pike de (ed.). The New Corporatism. [S.l.]: Notre Dame University Press, 1974.

SÜSSEKIND, Arnaldo et al. Instituições de Direito do Trabalho. 22. ed. Atualizada por Arnaldo Süssekind e João de Lima Teixeira Filho. São Paulo: LTr, 2005. v. 1.

VIANA, Márcio Túlio. Os Paradoxos da Conciliação: quando a ilusão da igualdade formal esconde mais uma vez a desigualdade real. Revista do Tribunal Regional do Trabalho da 3a Região, Belo Horizonte, v. 45, n. 75, p. 185-198, jan./jun. 2007.

Como citar este documento:

ASSUMPÇÃO, Luiz Felipe Monsores de. Projeções para um modelo de adjudicação administrativa de conflitos nas relações laborais no pós-reforma trabalhista e pósextinção do Ministério do Trabalho. Revista Opinião Jurídica, Fortaleza, v. 19, n. 31, p. 96-126, maio/ago. 2021. 